\title{
Perbedaan motivasi berpretasi dan dukungan sosial teman sebaya antara mahasiswa perantau dan non perantau di Fakultas Kedokteran Universitas Udayana
}

\author{
Nurul Lady Choirunisa dan Adijanti Marheni \\ Program Studi Sarjana Psikologi, Fakultas Kedokteran, Universitas Udayana \\ adijantimarheni@unud.ac.id
}

\begin{abstract}
Abstrak
Setiap individu berhak mendapatkan pendidikan setinggi-tingginya, salah satunya dengan menempuh perkuliahan di perguruan tinggi. Tujuan utama menjadi mahasiswa adalah mencapai prestasi akademik. Terdapat beberapa faktor yang memengaruhi antara lain motivasi berprestasi dan dukungan sosial teman sebaya. Motivasi berprestasi sebagai keinginan individu untuk menjalani proses perkuliahan dengan baik, sedangkan dukungan sosial teman sebaya sebagai bantuan dari teman dalam berbagai bentuk. Mahasiswa perantau dan non perantau memiliki kondisi yang berbeda, sehingga penelitian ini bertujuan untuk melihat perbedaan antara motivasi berprestasi dan dukungan sosial teman sebaya yang dimiliki oleh mahasiswa. Penelitian ini menggunakan metode kuantitatif dengan subjek sejumlah 238 mahasiswa yang sedang menempuh pendidikan di Fakultas Kedokteran Universitas Udayana yang dipilih menggunakan teknik cluster random sampling. Instrumen penelitian menggunakan skala motivasi berprestasi dan dukungan sosial teman sebaya. Analisis data menggunakan Independent Sample T-Test dengan hasil signifikansi sebesar $0,001(\mathrm{p}<0,05)$ pada motivasi berprestasi dengan mean empiris perantau lebih tinggi yaitu 110,38 dan mean empiris non perantau 106,98. Hasil signifikansi dukungan sosial teman sebaya sebesar $0,047(p<0,05)$ dengan mean empiris perantau lebih tinggi yaitu 173,70 dan mean empiris non perantau sebesar 170,95 . Hasil penelitian ini menunjukkan terdapat perbedaan motivasi berprestasi dan dukungan sosial teman sebaya antara mahasiswa perantau dan non perantau di Fakultas Kedokteran Universitas Udayana. Mahasiswa perantau memiliki motivasi berprestasi dan dukungan sosial yang lebih tinggi daripada mahasiswa non perantau.
\end{abstract}

Kata Kunci: Dukungan sosial teman sebaya, motivasi berprestasi, mahasiswa non perantau mahasiswa perantau.

\begin{abstract}
Every individual is entitled to get the highest education, one of them by taking lectures in college. The main goal of becoming a student is to achieve academic achievement. There are several factors that influence, among others, achievement motivation and peer social support. Achievement motivation as individual desire to undergo the process of lecturing well, while the social support of peers as a help from friends in various forms. Students of immigrants and non-immigrants have different conditions, so this study aims to see the difference between achievement motivation and peer social support owned by students. This study uses quantitative methods with the subject of 238 students who are studying at Faculty of Medicine Udayana University selected using cluster random sampling technique. The research instrument used achievement motivation scale and peer social support. Data analysis using Independent Sample T-Test with result of significance equal to $0,001(\mathrm{p}<0,05)$ on achievement motivation with higher immigrants empirical mean that is 110,38 and empirical mean of non- immigrants 106,98. Results of social support significance of $0.047(\mathrm{p}<0.05)$ with the higher immigrants empirical mean of 173.70 and non-immigrant empirical mean of 170.95 . The results of this study indicate there are differences in achievement motivation and social support of peers between immigrants and non immigrant students at the Faculty of Medicine Udayana University. Overseas students have higher achievement motivation and social support than non migrant students.
\end{abstract}

Keywords: Achievement motivation, immigrants, non-immigrants, peers social support. 


\section{LATAR BELAKANG}

Pendidikan adalah hal yang penting bagi setiap individu. Pendidikan merupakan pilar untuk membangun bangsa menjadi cerdas dan berintelektual. Fungsi pendidikan adalah membentuk sikap dan orientasi siswa terhadap belajar, menanamkan sikap positif, memberikan pengetahuan serta mengembangkan keterampilan belajar secara efektif. Semakin berkembangnya jaman dan semakin pesatnya kemajuan teknologi, maka tuntutan akan kualitas pendidikan semakin tinggi. Individu dari berbagai kalangan akan saling bersaing untuk menjadi yang terbaik, maka semakin banyak jumlah individu yang memilih meneruskan untuk menjadi mahasiswa.

Mahasiswa adalah orang yang belajar di perguruan tinggi. Usia mahasiswa pada umumnya berkisar 18-25 tahun untuk strata S1. Pendidikan tinggi berfungsi untuk mengembangkan kemampuan dan membentuk watak serta peradaban bangsa yang bermartabat dalam rangka mencerdaskan kehidupan bangsa. Hal ini membuktikan pemerintah mendukung siswa agar melanjutkan ke jenjang perguruan tinggi supaya dapat memajukan bangsa dari sisi pendidikan. Berdasarkan data tahun 2015, mahasiswa di Indonesia berjumlah 6.000 .000 orang (Nirmala, 2015). Jumlah ini tersebar di berbagai perguruan tinggi seperti negeri dan swasta, serta institut, sekolah tinggi, akademi dan sekolah lainnya. Sedangkan di Bali terdapat 100.000 mahasiswa yang mengenyam bangku kuliah pada tahun 2015 dan naik menjadi 113.000 mahasiswa pada tahun 2016 .

Hal yang paling penting untuk diraih oleh mahasiswa adalah prestasi akademik. Menurut Sardiman (2001), prestasi akademik adalah kemampuan nyata yang merupakan hasil dari interaksi antara berbagai faktor yang memengaruhi individu dalam belajar, baik dari dalam maupun luar diri. Prestasi akademik yang baik dipengaruhi oleh berbagai faktor, antara lain motivasi berprestasi dan dukungan sosial teman sebaya.

Hal ini ditunjukkan dengan penelitian oleh Sugiyanto (2010) tentang pentingnya motivasi berprestasi dalam mencapai keberhasilan proses pembelajaran. Motivasi berprestasi yang tinggi dapat memacu mahasiswa untuk terus belajar, rajin berkuliah dan berusaha menyelesaikan tugas perkuliahan sehingga mendapatkan hasil yang baik. Sedangkan apabila memiliki motivasi berprestasi yang rendah, maka mahasiswa akan cenderung bermalas-malasan, mengabaikan proses perkualiahan dan tidak berusaha menjadi mahasiswa yang baik.

Motivasi adalah sesuatu yang dapat memberikan energi, arah dan kegigihan tertentu, membuat individu dapat bergerak, terarah pada tindakan yang sudah dilakukannya (Ormrod, 2003). Motivasi paling utama bagi dunia pendidikan adalah motivasi berprestasi. Motivasi berpretasi adalah keinginan menyelesaikan sesuatu untuk mencapai suatu usaha guna mencapai kesuksesan (Santrock, 2003). Motivasi yang dimiliki individu dapat menjadi dorongan agar memiliki harapan untuk menjadi berprestasi hingga menjadi sukses. Jika individu memiliki motivasi tersebut, maka akan belajar lebih tekun serta memenuhi segala kewajibannya sebagai mahasiswa.
Mahasiswa S1 yang umunya berusia 18-22 tahun memasuki fase remaja akhir (Santrock, 2007). Hurlock (1999) menyatakan bahwa masa remaja adalah masa peralihan dari fase kanak-kanak menuju dewasa. Pada masa ini, remaja bukan lagi seorang anak dan juga bukan orang dewasa. Soesilo (1985) mengatakan bahwa dengan teman-teman sebaya, remaja memiliki kesempatan banyak untuk secara intim dalam hal berbicara sesuatu yang tidak ingin diketahui oleh orangtua. Teman sebaya dapat memberikan kepuasan kepada individu karena dapat mengerti dan memberikan simpati.

Hal ini menunjukkan bahwa mahasiswa sudah mulai membutuhkan teman sebagai bagian dari kehidupannya. Sebagian besar mahasiswa akan menggantungkan hidupnya melalui teman selain dengan orangtua. Sarafino (1994) menggambarkan dukungan sosial sebagai suatu kenyamanan, perhatian, penghargaan ataupun bantuan yang diterima individu dari orang lain maupun kelompok. Dukungan sosial adalah kehadiran orang lain yang dapat membuat individu percaya bahwa dirinya dicintai, diperhatikan dan merupakan bagian dari kehidupannya. Dukungan sosial dapat berasal dari orang-orang sekitar individu seperti keluarga, sahabat atau teman. Dukungan sosial teman sebaya adalah dukungan yang berasal dari teman-teman disekitar mahasiswa.

Dukungan sosial teman sebaya merupakan hubungan interpersonal yang berisi pemberian bantuan yang melibatkan aspek-aspek yang terdiri dari informasi, perhatian emosi, penilaian, bantuan instrumental, dukungan jaringan sosial yang diperoleh individu melalui interaksi dengan lingkungan, yang memiliki manfaat emosional atau efek perilaku bagi penerima sehingga dapat membantu individu dalam mengatasi masalahnya. Dukungan sosial teman sebaya yang tinggi dapat membuat mahasiswa lebih bersemangat menjalani proses perkuliahan. Hal ini disebabkan teman-teman disekitar dapat memberikan bantuan dan menemani disaat susah dan senang. Apabila dukungan sosial teman sebaya rendah, mahasiswa cenderung kurang mampu memecahkan masalah yang dimiliki, karena tidak ada teman sebagai tempat bercerita dan meminta pertolongan.

Sebagian besar perguruan tinggi berada di kota-kota besar, ibu kota provinsi atau daerah yang dianggap strategis. Meskipun demikian, tidak sedikit mahasiswa yang rela mencari pendidikan sejauh mungkin demi tercapai cita-citanya. Tidak sedikit mahasiswa yang rela berpindah menuju kota lain untuk dapat menempuh pendidikan yang diimpikan meskipun jaraknya jauh dari rumah, hal ini disebut dengan mahasiswa perantau. Mahasiswa perantau adalah individu yang berasal dari suatu tempat atau wilayah dan pindah untuk sementara pada wilayah lainnya. Mahasiswa non perantau adalah mahasiswa yang mengenyam pendidikan di wilayah asalnya.

Pemilihan populasi penelitian dilakukan di Universitas Udayana, karena Universitas Udayana merupakan universitas terbaik di Pulau Bali. Hal ini menyebabkan universitas ini diminati oleh mahasiswa dari luar Bali atau perantau. Fakultas Kedokteran Universitas Udayana dipilih karena jumlah mahasiswa perantau yang cenderung banyak. Hal ini didukung oleh data bahwa Fakultas Kedokteran menjadi fakultas di Universitas Udayana dengan jurusan yang paling diminati oleh 
siswa baik yang berasal dari Pulau Bali maupun luar Pulau Bali (Panestika, 2017).

Berdasarkan wawancara dengan mahasiswa perantau Fakultas Kedokteran Universitas Udayana yang berasal dari provinsi Jawa Timur, alasan memilih mengenyam pendidikan di Universitas Udayana karena memiliki akreditasi A. Hal ini mendorongnya untuk berkuliah dengan baik selama berada di kota yang jauh dari rumahnya. Pemilihan provinsi Bali dilakukan karena termasuk daerah yang maju dari sisi kesehatan, sehingga akan lebih mudah mencari pekerjaan. Sedangkan, seorang mahasiswa yang berasal dari Denpasar menyatakan alasan memilih Fakultas Kedokteran Universitas Udayana karena agar lebih dekat dengan orangtua. Alasan kedua adalah supaya tidak mengeluarkan biaya lebih untuk kebutuhan di kos atau tempat rantauan (Choirunisa, 2018).

Penelitian tentang perbedaan motivasi berprestasi ditunjukkan pada penelitian oleh Parmawati (2012) tentang perbedaan motivasi berprestasi mahasiswa perantau dan non perantau di Semarang. Hasil penelitian tersebut adalah mahasiswa perantau memiliki motivasi berprestasi yang lebih tinggi daripada mahasiswa non perantau. Faktor yang memengaruhi adalah faktor internal yaitu berasal dalam diri dan faktor eksternal yaitu keluarga, dan masyarakat. Motivasi berprestasi memiliki bermacam-macam bentuk, seperti tanggung jawab mengerjakan tugas, rajin kuliah setiap hari, mengerjakan ujian dengan jujur.

Terdapat penelitian oleh Iffah (2017), yang menyatakan bahwa mahasiswa perantau dan non perantau tidak memiliki perbedaan dalam motivasi untuk berprestasi. Mahasiswa yang tinggal bersama dengan orangtua maupun tinggal di asrama atau kos sama-sama memiliki keinginan untuk menjadi mahasiswa yang baik. Kendala yang dialami juga sama yaitu pengaturan waktu untuk belajar dan melakukan hal lainnya. Mahasiswa perantau terlalu banyak menghabiskan waktu untuk bermain dengan teman di kos dan mahasiswa non perantau banyak menghabiskan waktu untuk mengerjakan pekerjaan rumah.

Menjadi mahasiswa perantau, berarti tidak tinggal bersama orangtua. Hal ini membuat keadaan mahasiswa berbeda daripada mahasiswa non perantau yang tinggal dan dapat bertemu setiap hari dengan orangtuanya. Mahasiswa perantau mendapatkan sedikit perhatian dari orangtua karena kurangnya intensitas pertemuan. Diferiansyah (2015) menyatakan bahwa mahasiswa yang tinggal bersama orangtua tidak memiliki kecemasan sehingga dapat menjalani kuliah dengan baik. Mahasiswa perantau memiliki kerinduan pada orangtua sehingga akan mencari teman untuk menghilangkan kerinduan tersebut. Mahasiswa perantau awalnya akan mencari teman sesama perantau dahulu, sebelum mendapatkan teman non perantau. Kelompok teman sebaya yang positif akan sangat membantu remaja untuk memahami bahwa mereka tidak sendiri dalam menghadapi tantangan memenuhi tugastugasnya. Selain itu teman sebaya juga merupakan salah satu sumber dukungan sosial baik bagi mahasiswa yang tinggal bersama orangtua maupun tidak bersama orangtua atau tinggal di kos atau asrama.
Penelitian lain yang mendukung oleh Paramitha (2017) tentang dukungan sosial teman sebaya pada mahasiswa rantau yang sedang mengerjakan skripsi. Hasilnya adalah mahasiswa mendapat dukungan sosial dari teman, dukungan paling besar adalah teman mengajak untuk mengerjakan skripsi secara bersama-sama. Mahasiswa non perantau juga mendapatkan dukungan dari teman-teman nya, meskipun sehari-hari tinggal dengan orangtua.

Berdasarkan wawancara oleh seorang mahasiswa Fakultas Kedokteran Universitas Udayana yang menyatakan bahwa ia memiliki banyak teman sejak kecil hingga sekarang di Kota Denpasar. Setiap hari ia dan teman-temannya selalu menyempatkan diri untuk bersama baik di dalam kampus maupun luar kampus. Teman dapat memberikan bantuan di segala kondisi (Choirunisa, 2018). Namun hal berbeda ditunjukkan dari wawancara dengan seorang mahasiswa Fakultas Kedokteran Universitas Udayana angkatan 2010 yang berasal dari Kota Denpasar dan tinggal sehari-hari bersama orangtua, ia tidak menjalani kuliah dengan rajin. Hal ini disebabkan subjek tidak memiliki teman dekat di kampus sebagai tempat berkeluh kesah dan membantu permasalahan yang sedang dihadapi. Keluarga mengakui bahwa subjek jarang memiliki teman dekat yang dapat menemani setiap hari. Terdapat perbedaan keadaan mahasiswa perantau dan non perantau yang memengaruhi banyaknya motivasi berprestasi dan dukungan sosial teman sebaya. Oleh karena itu, penelitian ini dilakukan untuk mengetahui apakah terdapat perbedaan motivasi berprestasi dan dukungan sosial teman sebaya antara mahasiswa perantau dan non perantau di Fakultas Kedokteran Universitas Udayana. Hipotesis dalam penelitian ini adalah terdapat perbedaan motivasi berprestasi dan dukungan sosial antara mahasiswa perantau dan non perantau di Fakultas Kedokteran Universitas Udayana.

\section{METODE PENELITIAN}

\section{Variabel dan Definisi Operasional}

Variabel bebas dalam penelitian ini adalah status mahasiswa perantau dan non perantau serta variabel tergantung dalam penelitian ini adalah motivasi berprestasi dan dukungan sosial teman sebaya. Adapun definisi operasional dari masingmasing variabel dalam penelitian ini adalah sebagai berikut: Mahasiswa perantau dan non perantau

Mahasiswa perantau adalah mahasiswa yang berasal dari suatu tempat atau wilayah tertentu dan pindah untuk sementara menuju wilayah lainnya. Mahasiswa perantau memiliki tujuan untuk mengenyam pendidikan di perguruan tinggi. Dalam penelitian ini, mahasiswa perantau memiliki identitas di luar kota Denpasar dan tidak tinggal sehari-hari di alamat yang tertera pada kartu identitas milik orangtua dan tidak tinggal bersama orangtua.

Sedangkan penduduk non perantau adalah penduduk yang menetap di kota Denpasar atau memiliki KTP daerah Bali namun tinggal sehari-hari bersama orangtua dan tidak tergolong pada pengertian perantau.

Motivasi Berprestasi 
Motivasi berprestasi adalah keinginan untuk menyelesaikan sesuatu dengan melakukan suatu usaha untuk mencapai kesuksesan. Seseorang dianggap memiliki motivasi berprestasi jika mempunyai keinginan untuk melakukan karya yang memiliki prestasi lebih baik daripada prestasi orang lain. Motivasi berprestasi ini akan diukur menggunakan kuesioner yang dibuat peneliti menggunakan skala Likert berdasarkan aspek-aspek yang disampaikan oleh Mcclelland (dalam Hawadi, 2001). Semakin tinggi skor total yang diperoleh, maka semakin tinggi taraf motivasi berprestasi yang dimiliki.

Dukungan Sosial Teman Sebaya

Dukungan sosial adalah salah satu fungsi dari ikatan sosial yang menggambarkan kualitas umum dari hubungan interpersonal. Dukungan sosial diartikan dengan keberadaan, kesediaan, kepedulian dari orang-orang yang dapat diandalkan, menghargai, dan menyayangi. Dukungan ini bersumber dari teman sebaya atau teman yang memiliki usia yang hampir sama. Dukungan sosial ini akan diukur menggunakan kuesioner yang dibuat peneliti menggunakan skala Likert berdasarkan aspek-aspek yang disampaikan oleh Sarafino (1998). Semakin tinggi skor total yang diperoleh, maka semakin tinggi taraf dukungan sosial teman sebaya yang dimiliki.

\section{Responden}

Populasi dalam penelitian ini adalah seluruh mahasiswa Fakultas Kedokteran Universitas Udayana. Sampel pada penelitian ini memiliki karakteristik (1) Mahasiswa Fakultas Kedokteran Universitas Udayana, (2) Sedang menempuh pendidikan semester 1-8, (3) Berusia 18-22 tahun. Pada periode ini individu sedang berada pada fase remaja khususnya remaja akhir. (4) Berjenis kelamin laki-laki dan perempuan

Teknik pengambilan sampel yang digunakan dalam penelitian ini adalah cluster sampling. Pada penelitian ini dilakukan cluster sampling dengan dua tahap (Two Stages Cluster sampling). Tahap pertama adalah memilih jurusan atau program studi, di Fakultas Kedokteran Universitas Udayana terdapat 6 jurusan yaitu Kedokteran umum, Psikologi, Keperawatan, Fisioterapi, Kesehatan Masyarakat dan Kedokteran Gigi. Tahap kedua adalah menentukan tahun angkatan, mahasiswa aktif Fakultas Kedokteran Universitas Udayana adalah 2014, 2015, 2016, dan 2017.

\section{Tempat Penelitian}

Penelitian ini dilaksanakan pada tanggal 20 Desember 2017 di Program Studi Fisioterapi angkatan 2016 dan 2017 serta tanggal 21 Desember 2017 di Pendidikan Dokter angkatan 2015. Jumlah kuesioner yang disebar dalam penelitian ini adalah sejumlah 300 buah. Kuesioner yang dapat dianalisis berjumlah 238 buah dengan rincian 89 kuesioner mahasiswa perantau dan 149 kuesioner mahasiswa non perantau.

\section{Alat Ukur}

Alat ukur yang digunakan dalam penelitian ini adalah Skala Motivasi Berprestasi dan Skala Dukungan Sosial Teman Sebaya. Skala dalam penelitian ini memiliki aitem yang disusun menjadi aitem favorable dan unfavorable dengan empat kategori pilihan jawaban yaitu sangat setuju (SS), setuju (S), tidak setuju (TS) dan sangat tidak setuju (STS). Skala Motivasi berprestasi diukur menggunakan empat aspek yaitu tanggung jawab, kreatif inovatif, mempertimbangkan resiko serta memperhatikan umpan balik yang disampaikan oleh Mcclelland (dalam Hawadi, 2001). Skala Dukungan Sosial Teman Sebaya disusun berdasarkan empat aspek dari Sarafino (1998) sayaitu dukungan emosional, penghargaan, instrumental serta informasi. Skala Motivasi Berprestasi memiliki 37 aitem dan Skala Dukungan Sosial Teman Sebaya memiliki 58 aitem.

Uji reliabilitas dan uji validitas dilakukan sebelum pengambilam data. Uji validitas dilakukan dengan profesional judgement dengan dosen pembimbing. Uji reliabilitas dalam penelitian ini menggunakan formula Alfa Cronbach, skaladianggap layak dipakai jika memilki koefisien realibilitas $\geq 0,6$. Hasil uji validitas Skala Motivasi Berprestasi memiliki koefisien validitas pada rentang 0,302 sampai dengan 0,670. Hasil uji reliabilitas menunjukkan koefisien Alpha $(\alpha)$ sebesar 0,905 yang menunjukkan $90,5 \%$ variasi skor murni. Hasil uji validitas Skala Dukungan Sosial Teman Sebaya memiliki koefisien validitas pada rentang 0,371 sampai dengan 0,808 . Hasil uji reliabilitas menunjukkan koefisien Alpha $(\alpha)$ sebesar 0,971yang menunjukkan $97,1 \%$ variasi skor murni.

\section{Teknik Analisis Data}

Uji hipotesis dilakukan apabila data peneletian telah melewati syarat uji asumsi yaitu uji normalitas, uji linearitas, dan uji multikolinearitas. Uji normalitas pada penelitian ini menggunakan uji Kolmogorov Smirnov, uji linearitas dilakukan dengan menggunakan uji Compare Means, dan uji multikolinearitas dilakukan dengan melihat nilai Variance Inflation Factor (VIF) dan nilai Tolerance. Setelah melakukan uji asumsi, data penelitian dianalisis dengan menggunakan metode analisis regresi berganda untuk menguji hipotesis mayor dan hipotesis minor. Analisis data dilakukan dengan menggunakan bantuan software SPSS release 20.0.

\section{HASIL PENELITIAN}

\section{Karakteristik Subjek}

Responden dalam penelitian ini adalah mahasiswa Program Studi Fisioterapi semester I dan III, serta mahasiswa Program Studi Pendidikan Dokter semester V yang berjumlah 238 orang. Responden mayoritas berjenis kelamin perempuan, yaitu sebesar $60,67 \%$ pada kelompok perantau dan $66,44 \%$ pada kelompok non perantau. Usia responden penelitian mayoritas 20 tahun, yaitu sebesar $40,45 \%$ pada kelompok perantau dan $50,34 \%$ pada kelompok non perantau.

\section{Deskripsi Data Penelitian}

(tabel 1. Deskripsi motivasi berprestasi. terlampir) Skor motivasi berprestasi terendah ditunjukkan oleh subjek pada kelompok non perantau yaitu 86, sedangkan skor tertinggi ditunjukkan oleh kedua kelompok perantau dan non perantau sebesar 127. Rata-rata teoretis menujukkan angka 92,5 dan rata-rata empiris menunjukkan angka 110,38 pada perantau dan 106,98 pada non perantau. Nilai rata-rata empiris yang didapatkan lebih besar dari nilai rata-rata teoretis (rata-rata 
empiris $>$ rata-rata teoretis), sehingga menunjukkan bahwa subjek penelitian memiliki motivasi berprestasi yang tinggi daripada populasi.

(tabel 2. Deskripsi statistik dukungan sosial teman sebaya. terlampir) Skor dukungan sosial teman sebaya terendah ditunjukkan oleh subjek pada kelompok non perantau yaitu 141, sedangkan skor tertinggi ditunjukkan oleh kelompok non perantau yaitu 197. Rata-rata teoretis menujukkan angka 145 dan rata-rata empiris menunjukkan angka 173,70 pada perantau dan 170,95 pada non perantau. Nilai rata-rata empiris yang didapatkan lebih besar dari nilai rata-rata teoretis (ratarata empiris $>$ rata-rata teoretis), sehingga menunjukkan bahwa subjek penelitian memiliki dukungan sosial teman sebaya lebih tinggi daripada populasi.

\section{Uji Asumsi}

Uji normalitas dalam penelitian yang digunakan untuk mengetahui apakah data dapat berdisribusi normal (Sugiyono, 2014). Uji normalitas dalam penelitian ini meggunakan uji Kolmogorov Smirnov. Data akan berdistribusi normal apabila memiliki nilai signifikansi lebih besar dari 0,05 ( $>0,05)$. Berdasarkan tabel 3 (terlampir), didapatkan hasil motivasi berprestasi memiliki $\mathrm{p}$ sebesar 0,100 dan dukungan sosial teman sebaya memiliki p sebesar 0,083 sehingga penelitian ini memiliki data yang berdistribusi normal $(\mathrm{p}>0,05)$.

Uji Homogenitas dalam penelitian ini menggunakan Levene Test. Data bersifat homogenapabila memiliki nilai signifikansi lebih besar dari 0,05 ( $>>0,05)$. Berdasarkan tabel 4 (terlampir), dapat dilihat bahwa skala motivasi berprestasi memiliki probabilitas (p) 0,547 dan dukungan sosial teman sebaya memiliki probabilitas (p) 0,439. Maka kedua angka tersebut menunjukkan bahwa tidak ada perbedaan varians antara kedua kelompok atau data homogen.

\section{Uji Hipotesis}

Uji hipotesis dalam penelitian ini menggunakan Independent Sample T-Test. Uji Independent Sample T-Test digunakan untuk mengetahui apakah ada perbedaan rata-rata (mean) antara dua populasi dengan melihat rata-rata dua sampel. Uji ini digunakan dalam penelitian komparatif. Berdasarkan tabel 5 (terlampir), diketahui bahwa $\mathrm{t}$ pada skala motivasi berprestasi menunjukkan angka 3,258 dengan probabilitas (p) sebesar 0,001. Sedangkan t pada skala dukungan sosial teman sebaya menunjukkan angka sebesar 1,993 dengan probabilitas (p) sebesar 0,047. Kedua skala pada Independent Sample TTest menunjukkan angka probabilitas di bawah 0,05 $(\mathrm{p}<0,05)$, sehingga $\mathrm{H}_{0}$ ditolak dan $\mathrm{H}_{\mathrm{a}}$ diterima, maka ada perbedaan motivasi berprestasi dan dukungan sosial teman sebaya antara mahasiswa perantau dan non perantau di Fakultas Kedokteran Universitas Udayana. (tabel 6. Rangkuman hasil uji hipotesis penilitian. terlampir).

\section{PEMBAHASAN DAN KESIMPULAN}

Berdasarkan hasil penelitian yang telah dilakukan, maka terdapat perbedaan motivasi berprestasi dan dukungan sosial pada mahasiswa perantau dan non perantau di Fakultas Kedokteran Udayana. Hal ini ditunjukkan dengan analisis menggunakan Independent Sample T-Test, pada variabel motivasi berprestasi diperoleh angka probabilitas sebesar 0,001 yang berarti di bawah $0,05 \quad(p<0,05)$ sehingga membuktikan bahwa terdapat perbedaan antara kelompok perantau dan non perantau. Mahasiswa perantau di Fakultas Kedokteran Udayana memiliki motivasi berprestasi lebih tinggi daripada mahasiswa non perantau. Hal ini ditunjukkan dengan rata-rata skor mahasiswa perantau sebesar 110,38, sedangkan rata-rata skor mahasiswa non perantau sebesar 106,98. Hal ini menunjukkan bahwa mahasiswa perantau memiliki motivasi berprestasi yang lebih tinggi daripada mahasiswa non perantau.

Hal ini didukung penelitian oleh Muallim (2016) yang menyatakan bahwa antara mahasiswa perantau dan non perantau memiliki perbedaan motivasi berprestasi. Mahasiswa perantau memiliki motivasi berprestasi yang lebih tinggi daripada motivasi berprestasi mahasiswa non perantau. Sejalan dengan pernyataan Hidayat (2008) yang menyatakan bahwa mahasiswa perantau yang cenderung menjadi bintang kelas atau memiliki motivasi berprestasi yang lebih besar daripada mahasiswa non perantau. Hal ini disebabkan karena mahasiswa non perantau merasa hidupnya berkecukupan saat menempuh kuliah dan tinggal bersama orangtua sehingga mendapatan proteksi.

Perbedaan tanggung jawab yang dimiliki mahasiswa, dinyatakan oleh Sumita (2017), bahwa mahasiswa perantau memiliki kebutuhan yang harus dipenuhi dan kebutuhan tersebut berupa tuntutan untuk menyelesaikan pendidikan dan tanggung jawab terhadap kepercayaan orangtua. Sebagai upaya untuk mencapai kesuksesan, maka mahasiswa perantau akan memiliki kesadaran untuk melaksanakan tanggung jawab untuk mencapai tujuan. Tanggung jawab itu antara lain mengerjakan tugas saat kuliah, rajin masuk kuliah dan mengerjakan sendiri tugas yang wajib dikerjakan mahasiswa.

Mahasiswa yang memiliki tanggung jawab untuk mencapai kesuksesan, akan mencari cara untuk menyelesaikan tugasnya dengan baik. Mahasiswa akan meningkatkan kreativitas dan inovasi, memperhatikan umpan balik yang diberikan orang lain dan memperhatikan risiko dalam mengambil suatu tugas. Mahasiswa perantau memiliki motivasi berprestasi yang lebih tinggi daripada mahasiswa non perantau, karena mahasiwa perantau tinggal jauh dari orangtua, hal ini membuat mahasiswa berusaha untuk membahagiakan orangtua dan mencari kehidupan yang lebih baik sehingga dalam diri mahasiswa memiliki motivasi berprestasi yang lebih tinggi. Lain halnya dengan mahasiswa non perantau yang tinggal bersama orangtua dan keluarga akan lebih mendapat perlindungan.

Nilai rata-rata empiris yang didapatkan mahasiswa perantau sebesar 110,38 dan mahasiswa non perantau sebesar 106,98, sedangkan nilai teoretis keduanya sebesar 92,5. Maka nilai empiris lebih besar dari nilai rata-rata teoretis (rata-rata empiris $>$ rata-rata teoretis), sehingga menunjukkan bahwa subjek penelitian memiliki motivasi berprestasi yang lebih 
tinggi daripada populasi. Hal ini disebabkan setengah dari subjek penelitian adalah mahasiswa semester III dan $\mathrm{V}$ sehingga sudah mendekati akhir masa studinya. Hal ini sejalan dengan pernyataan Darmawati (2013), mahasiswa semester I dan II belum memiliki motivasi berprestasi yang tinggi. Hal ini disebabkan mahasiswa baru mengenal dunia perkuliahan dan belum mengerti sistem pendidikan di perguruan tinggi. Pada saat memasuki semester III, mahasiswa akan mulai mengerti sistem di perkuliahan dan meningkatkan motivasi untuk mencapai prestasi dalam perkuliahan. Motivasi ini cenderung terus meningkat hingga akhir masa studi dan proses menyelesaikan skripsi.

Santrock (2003) menyatakan bahwa mahasiswa yang berada dalam fase remaja akhir memiliki kecenderungan untuk terikat dengan teman sebayanya. Kelompok teman sebaya dapat memberikan umpan balik pada remaja mengenai kemampuan mereka baik prestasi akademik maupun hal lainnya dan membandingkan dengan remaja yang lain. Hal ini tidak dapat dilakukan kepada orangtua atau saudara kandung yang lebih tua ataupun lebih muda. Sehingga mahasiswa yang sedang dalam fase remaja cenderung lebih banyak menghabiskan waktu interaksi dengan teman sebaya dan menganggap hubungan dengan remaja merupakan bagian besar dari hidupnya.

Pada variabel dukungan sosial juga ditemukan perbedaan antara kelompok perantau dan non perantau, hal ini dibuktikan dengan angka probabilitas sebesar 0,047 $(\mathrm{p}<0,05)$. Mahasiswa perantau di Fakultas Kedokteran Udayana memiliki dukungan sosial teman sebaya lebih tinggi daripada mahasiswa non perantau. Hal ini ditunjukkan dengan rata-rata skor mahasiswa perantau sebesar 173,70 . Sedangkan rata-rata skor mahasiswa non perantau sebesar 170,95. Hal ini menunjukkan bahwa mahasiswa perantau memiliki dukungan sosial teman sebaya yang lebih tinggi daripada mahasiswa non perantau.

Hal ini sejalan dengan pernyataan Syahrina (2016) bahwa mahasiswa perantau yang berada jauh dari orangtua dan tinggal di asrama atau kos-kosan menghabiskan lebih banyak interaksi dengan teman sebaya. Interaksi yang terjalin dengan teman sebaya di tempat tinggal mahasiswa saling memberikan penilaian satu sama lain, mendapatkan informasi, mendapat kasih sayang dan mendukung kegiatan yang dilakukan sehingga memberikan pengaruh positif pada mahasiswa perantau.

Pada mahasiswa non perantau, dukungan sosial yang didapatkan tidak hanya berasal dari teman sebaya, namun juga berasal dari orangtua dan keluarga. Hal ini disebabkan karena mahasiswa tinggal bersama orangtua dan membagi waktu antara interaksi dengan orangtua serta keluarga dan teman sebaya. Mahasiswa memiliki dukungan sosial dari orangtua dan teman sebaya sehingga memiliki prestasi akademik yang positif (Suciani, 2014).

Dukungan sosial teman sebaya lebih banyak didapatkan mahasiswa perantau karena mahasiswa perantau tidak tinggal berdekatan dengan keluarga, sehingga lebih banyak menghabiskan waktu dengan teman sebaya. Sedangkan mahasiswa non perantau memiliki interaksi langsung dengan orangtua dan keluarga di rumah sehingga membagi waktu antara berinteraksi dengan orangtua serta keluarga dan teman sebaya. Nilai rata-rata empiris yang didapatkan mahasiswa perantau sebesar 173,70 dan mahasiswa non perantau sebesar 170,95, sedangkan nilai teoretis keduanya sebesar145. Maka nilai empiris lebih besar dari nilai rata-rata teoretis (rata-rata empiris $>$ rata-rata teoretis), sehingga menunjukkan bahwa subjek penelitian memiliki dukungan sosial teman sebaya yang lebih tinggi daripada populasi. Subjek dalam penelitian ini mayoritas memiliki umur 19 dan 20 tahun, dan masuk dalam kategori remaja akhir. Pada masa remaja akhir, hubungan mahasiswa dengan teman sebaya akan menjadi lebih penting daripada orangtua. Mahasiswa akan cenderung menghabiskan waktu lebih banyak dengan teman sebaya pada akhir masa remaja (Furhma \& Buhrmester dalam Missasi, 2015).

Berdasarkan seluruh pemaparan pada penelitian ini, maka didapatkan kesimpulan bahwa terdapat perbedaan motivasi berprestasi dan dukungan sosial teman sebaya antara mahasiswa perantau dan non perantau di Fakultas Kedokteran Universitas Udayana. Motivasi berprestasi yang dimiliki mahasiswa perantau lebih tinggi daripada mahasiswa non perantau. Hal yang sama juga terjadi pada dukungan sosial teman sebaya yang dimiliki mahasiswa perantau lebih tinggi daripada mahasiswa non perantau. Saran bagi peneliti selanjutnya, yaitu diharapkan mampu memastikan subjek penelitian mengisi data atau aitem dalam kuisioner dengan lengkap agar seluruh aitem dapat dianalisis

\section{DAFTAR PUSTAKA}

Akbar, R., \& Hawadi. (2001). Psikologi perkembangan anak mengenal sifat, bakat, dan kemampuan anak. Jakarta: Gramedia Widiasarana Indonesia.

Choirunisa, N.L. (2017). Studi kasus: gambaran motivasi berprestasi mahasiswa Fakultas Kedokteran Universitas Udayana. (Naskah tidak dipublikasikan). Program Studi Psikologi, Fakultas Kedoteran, Universitas Udayana, Denpasar.

Darmawati. (2013). Pengaruh motivasi belajar dan gaya belajar terhadap prestasi belajar ekonomi siswa SMA negeri di Kota Tuban. Jurnal Ekonomi dan Kewirausahaan, 1(1), 7990. Diakses pada 28 Desember 2017 dari https://scholar.google.co.id/citations?user=wRmSKW8AA AAJ\&hl=en

Diferiansyah, O. (2015). Perbedaan tingkat gelisah antara mahasiswa Kedokteran tingkat pertama yang tinggal kost dan bersama orangtua. Jurnal Kedokteran, 4(6), 16-19. Diakses pada 2 Januari 2018 dari http://juke.kedokteran.unila.ac.id/ index.php/majority/article/view/1389/1225

Hurlock, B.E. (1999). Psikologi perkembangan, suatu pendekatan sepanjang rentang kehidupan (edisi kelima). Jakarta: Penerbit Erlangga.

Iffah, F. (2017). Perbedaan motivasi dan prestasi belajar antara mahasiswa penglaju dan mahasiswa kos. (Skripsi dipublikasikan). Fakultas Ilmu Tarbiyah dan Keguruan Universitas Islam Negeri, Jakarta. Diakses pada 3 Januari 2018 dari http://repository.uinjkt.ac.id/dspace/handle/123456789/345 12 
Missasi. (2015). Hubungan antara kualitas persahabatan dan self esteem dengan loneliness. (Skripsi tidak dipublikasikan). Fakultas Psikologi Universitas Islam Negeri, Pekanbaru.

Muallim. (2016). Perbedaan prestasi akademik antara mahasiswa pendatang dan mahasiswa lokal. (Skripsi tidak dipublikasikan) Program Studi Pendidikan Sosiologi Universitas Negeri Makassar.

Naim, M. (1979). Merantau pola migrasi Suku Minangkabau. Yogyakarta: Gajah Mada University Press.

Nirmala, I., \& Attamimi. (2015). Statistik pendidikan tinggi 2014/2015. Jakarta: PDDIKTI Kemristekdikti

Ormrod, J.E. (2003). Educational psychology developing learners (4th ed). USA: Merill Prentice Hall.

Panestika, A. (2015, 20 Desember). Peminat dan daya tampung kampus terbaik di Indonesia 2017. Diakses pada 21 Desember 2017 dari Gen Muda. Org http://www.genmuda.com/yuk-cek-peminat-dan-dayatampung-10-kampus terbaik-di-indonesia-tahun-2017/

Paramitha. (2017). Dukungan sosial dari teman sebaya pada mahasiswa rantau yang sedang mengerjakan tugas akhir. (Skripsi Dipublikasikan). Fakultas Psikologi Universitas Sanata Dharma. Diakses pada 5 Januari 2018 dari https://repository.usd.ac.id/12174/

Parmawati, R. (2008). Perbedaan motivasi berprestasi antara mahasiswa perguruan tinggi negeri-Swasta diinjau dari mahasiswa pendatang- bukan pendatang. (Naskah Tidak Dipublikasikan). Fakultas Psikologi Universitas Muhammadiyah Surakarta.

Santrock, J.W. (2003). Adolescence perkembangan remaja(edisi enam). Jakarta: Erlangga

Santrock, J.W. (2007). Remaja edisi 11 jilid 1. Jakarta: Erlangga.

Sarafino, E.P. (1994). Health psychology 2ed . New York: John Wiley \& Sonc, Inc.

Sarafino, E.P. (1998). Health psychology,biopsychosocial interactions third edition. United States of American: John Wiley \& Sonc, Inc.

Sardiman, A.M. (2010). Interaksi dan motivasi belajar mengajar. Jakarta: Raja Grafindo Persada.

Soesilo, L.S. (1985). Peranan teman dalam penyesuaian sosial. Jakarta: Rajawali Press.

Suciani. (2014). Hubungan dukungan sosial dengan motivasi belajar pada mahasiswa Universitas Esa Unggul. Jurnal Psikologi 12(2), 1-5. Diakses pada 10 Januari 2018 dari http://ejurnal.esaunggul.ac.id/index.php/psiko/article/view/ $1451 / 1321$

Sugiyanto. (2009). Kontribusi motivasi berprestasi terhadap prestasi akademik siswa kelas XI SMA Negeri 10 Semarang. Jurnal Pendidikan, 1(8), 19-34. Diakses pada 30 Januari 2018 dari https://journal.uny.ac.id/index.php/paradigma/article/view/5 932

Sugiyono. (2014). Metode penelitian kuantitatif kualitatif. Bandung: Alfabeta.

Sumita. (2017). Motif mahasiswa perantau Kalimantan dalam melanjutkan pendidikan (Naskah tidak dipublikasikan). Program Studi Pendidikan Agama Buddha STABN Sriwijaya, Banten.

Syahrina. (2016). Pengaruh dukungan sosial teman sebaya terhadap tingkat kemandirian pada mahasiswa yang merantau di Kota Makassar. (Skripsi tidak dipublikasikan). Fakultas Psikologi Universitas Negeri Makassar.

Turner, P., Sarason, G.I., \& Sarason, B.R. (2001). Exploring the link between parental acceptance and young adults adjustment. Journal Terapi Kognitif dan Riset, 25(2), 185-199. Diakses pada 23 Desember 2017 dari https://link.springer.com /article/10.1023/A:1026420025379 


\section{LAMPIRAN}

Tabel 1

Deskripsi statistik motivasi berprestasi

\begin{tabular}{lll}
\hline Kelompok & Perantau & Non Perantau \\
\hline Min & 94 & 86 \\
Max & 127 & 127 \\
Mean Teoretis & 92,5 & 92,5 \\
Mean Empiris & 110,38 & 106,98 \\
SD Teoretis & 18,5 & 18,5 \\
SD Empiris & 7,256 & 8,097 \\
Varian Teoretis & $37-148$ & $37-148$ \\
Varian Empiris & $94-127$ & $86-127$ \\
T & 30,566 & 30,566 \\
& $\mathrm{P}=(0,000)$ & $\mathrm{P}=(0,000)$ \\
\hline
\end{tabular}

Tabel 2

Deskripsi statistik dukungan sosial teman sebaya

\begin{tabular}{lll}
\hline Kelompok & Perantau & Non Perantau \\
\hline Min & 145 & 141 \\
Max & 193 & 197 \\
Mean Teoretis & 145 & 145 \\
Mean Empiris & 173,70 & 170,95 \\
SD Teoretis & 29 & 29 \\
SD Empiris & 10,174 & 10,377 \\
Varian Teoretis & $58-232$ & $58-232$ \\
Varian Empiris & $145-193$ & $141-197$ \\
T & 40,144 & 40,144 \\
& $\mathrm{P}=(0,000)$ & $\mathrm{P}=(0,000)$ \\
\hline
\end{tabular}


Tabel 3

Hasil uji normalitas data penelitian

\begin{tabular}{llll}
\hline Skala & Kolmogorov Smirnov & Sig. & Kesimpulan \\
\hline Motivasi Berprestasi & 1,225 & 0,100 & Data Normal \\
Dukungan Sosial & 1,262 & 0,083 & Data Normal \\
Teman Sebaya & & & \\
\hline
\end{tabular}

Keterangan: Sig. = nilai probabilitas

Tabel 4

Hasil uji homogenitas data penelitian

\begin{tabular}{llll}
\hline Skala & F & Sig. & Keterangan \\
\hline Motivasi Berprestasi & 0,364 & 0,547 & Data Homogen \\
Dukungan Sosial Teman & 0,602 & 0,439 & Data Homogen \\
Sebaya & & & \\
Keterangan: Sig. = nilai probabilitas & &
\end{tabular}

Tabel 5

Hasil uji hipotesis data penelitian

\begin{tabular}{llll}
\hline Skala & T & Sig. (2 Tailed) & Keterangan \\
\hline Motivasi Berprestasi & 3,258 & 0,001 & Ho ditolak \\
& & & Ha diterima \\
Dukungan Sosial Teman & 1,993 & 0,047 & Ho ditolak \\
Sebaya & & & Ha diterima \\
\hline
\end{tabular}

Keterangan: Sig. (2 Tailed $)=$ nilai probabilitas 
Tabel 6

Rangkuman hasil uji hipotesis penelitian

\begin{tabular}{clc}
\hline No & \multicolumn{1}{c}{ Hipotesis } & Hasil \\
\hline 1. & Terdapat perbedaan motivasi berprestasi antara mahasiswa perantau & Diterima \\
& dan non perantau di Fakultas Kedokteran Universitas Udayana. & \\
& & \\
\hline 2. & Terdapat perbedaan dukungan sosial teman sebaya antara mahasiswa & Diterima \\
& $\begin{array}{l}\text { perantau dan non perantau di Fakultas Kedokteran Universitas } \\
\text { Udayana. }\end{array}$ & \\
\end{tabular}

